\title{
Synthesis and Evaluation of Antioxidant Activity of Some New Heterocyclic Compounds Bearing the Benzo[B]Furan Moiety
}

\author{
Marwa Abdel-motaal, \\ E. M. Kandeel, \\ M. Abou-Elzahab, \\ F. Elghareeb. \\ Department of chemistry, faculty of science, \\ Mansoura University, Mansoura, Egypt
}

Doi: 10.19044/esj.2017.v13n30p297 URL:http://dx.doi.org/10.19044/esj.2017.v13n30p297

\begin{abstract}
New compounds were synthesized by the reaction of 3-acetyl-5methoxy-2-methylbenzofuran (1) with cyanoacetylhydrazine which afforded the hydrazide hydrazone derivative $\mathbf{2}$. Compound $\mathbf{2}$ underwent a series of heterocyclization reactions to give the new pyrazole, isoxazole, cyclopentanothiophene, thiazole, triazole, $2 \mathrm{H}$-chromene and pyridone derivatives (3-13). The elemental and spectral data (IR, ${ }^{1} \mathrm{H}$ NMR and MS) characterized their structures. Screening for some selected compounds was carried for their potential antioxidant activities using ABTS. Among the tested samples compounds $\mathbf{9 , 1 1 , 5}$ and $\mathbf{1 0}$ exhibited promising activity.
\end{abstract}

Keywords: Cyanoacetylhydrazine, benzo[b]furan, binary heterocyclic systems, antoxidant activity

\section{Introduction}

Benzofuran is a privileged pharmacophore widely existing in numerous natural products, biologically active compounds and pharmaceuticals (Messina et al., 2000; Yeung K. S., 2012). Accordingly, flurry of synthetic methods have been devoted to the development of synthetic approaches for benzofuran containing heterocycles (Gadaginamath et al., 2003). In particular, compounds bearing the benzo[b]furan structural framework have stimulated significant interest due to their biological importance (Verma et al., 2011; Deshpande et al., 2012) such as antiinflammatory (Yadav et al., 2014; Xiea et al., 2014), antimicrobial (Hirosato et al., 2002), antifungal (Khan et al., 2005), antituberecular (Prado et al., 
2006; Manna et al., 2010) , antihyperglycemic (Hsieh et al., 2015), analgesic( El-Sawy et al., 2014), antiviral (Malpania et al., 2014; Takaya et al., 2011; Gopalsamy et al., 2006; Rida et al., 2006), and anticancer activities (Parekh et al., 2011; Hranjec et al., 3013., Wang et al., 2013; Baraldi et al., 2003; Romagnoli et al., 2009; Kamal et al., 2014). Within this context, benzo[b]furan-based compounds acquired considerable attention from the pharmaceuticals markets as they constitute the core scaffold of several bioactive compounds and many marketed drugs such as Galantamine (I) which used in treatment of mild to moderate Alzheimer's disease, Tasimelton (II) which used in the treatment of non-24-h sleep-wake disorder (N24HSWD), Ramlteon (III) which used in the treatment of delayed sleep phase syndrome, Psoralen (IV) which used in the treatment for psoiasis, eczema, vitiligo and cutaneous T-cell lymphoma, Trioxsalen $(\mathbf{V})$ which act as photosensitizer used to increase skin tolerance to sunlight and enhance pigmentation and Methoxsalen (VI) which used to treat psoriasis, eczema, vitiligo, cutaneous lymphomas (Reshma et al., 2015) (Figure 1).

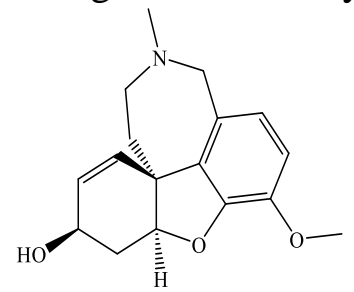

I

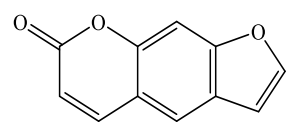

IV

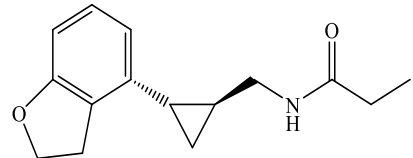

II

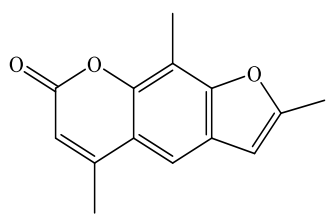

V

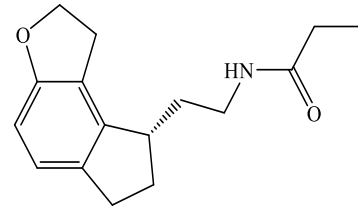

III

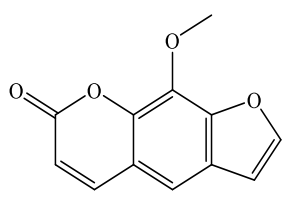

VI

Figure 1

It is worth noting that benzo[b]furan ring systems bearing various substituents at the C-3 position represent a significant source of inspiration for the design of structural analogues with improved medicinal profiles in pharmaceutical chemistry. This group of heterocycles is usually clinically more potent moiety and possesses diverse pharmacological properties and profound efficacy. Benzbromarone (VII) used in treatment of gout, benzofuran derivative VIII act as tubulin polymerization and growth of MCF-7 cell lines inhibitors(Wu et al., 2013) and benzofuran-3yl(phenyl)methanones IX considers an inhibitor of SIRT1 which important in the treatment of cancer diabetes (Flynn et a., 2002) (figure 2). 


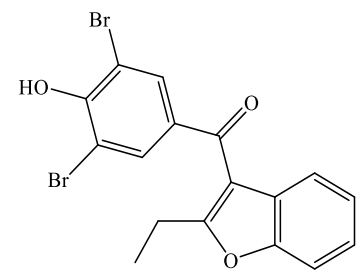

VII

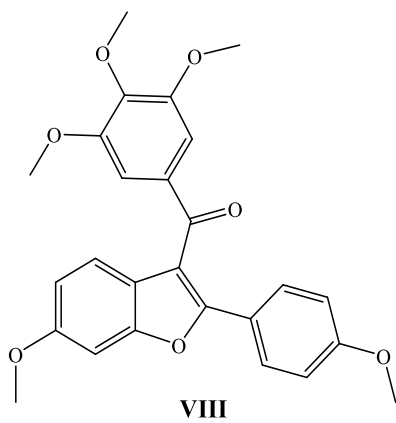

Figure 2

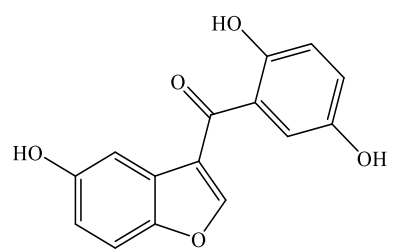

IX

In continuation of our previous work (Abdel-Rahman et al., 2013; Berghot et al., 2014; Bondock et al., 2008; Metwally et al., 2011; El-Desoky et al., 1998) in the synthesis of heterocyclic compounds that are biologically active, we herein report the synthesis of benzo[b]furan-containing compounds with diverse heterocyclic functionality (e.g., oxazole, pyrazole, thiophene, thiazole, triazole and 2-pyridone) at C-3 position. The corresponding antioxidant profile of these compounds will be evaluated using ABTS antioxidant assay.

\section{Result and discussion}

2-Cyano- $N$-[1-(5-methoxy-2-methylbenzofuran-3yl)ethylidene]acetohyd- razide (2) was prepared via the condensation of 3acetyl-5-methoxy-2-methylbenzofuran (1) (Guru et al., 2003) with cyanoacetohydrazide in ethanol containing a catalytic amount of acetic acid. The structure of compound $\mathbf{2}$ was confirmed based on its analytical and spectral data. The infrared spectrum exhibited absorption bands at 3197 $(\mathrm{NH}), 2262(\mathrm{CN})$ and $1683 \mathrm{~cm}^{-1}$ for $(\mathrm{CO})$. The ${ }^{1} \mathrm{H}$ NMR spectrum in DMSO$\mathrm{d}_{6}$ showed signals at $\delta(\mathrm{ppm}): 2.34\left(\mathrm{~s}, 3 \mathrm{H}, \mathrm{CH}_{3}\right), 2.57\left(\mathrm{~s}, 3 \mathrm{H}, \mathrm{CH}_{3}\right), 3.80$ $\left(\mathrm{s}, 3 \mathrm{H}, \mathrm{OCH}_{3}\right), 4.23\left(\mathrm{~s}, 2 \mathrm{H}, \mathrm{CH}_{2}\right), 6.8-7.8(\mathrm{~m}, 3 \mathrm{H}, \mathrm{Ar}-\mathrm{H}), 11.00(\mathrm{~s}, 1 \mathrm{H}, \mathrm{NH})$. Its

${ }^{13} \mathrm{C}$-NMR spectrum showed two important signals characteristic of carbon atoms from $\mathrm{C}=\mathrm{O}$ and $\mathrm{CN}$ groups at $\delta 165.55$ and $160 \mathrm{ppm}$, respectively. The mass spectrum showed a molecular ion peak at $\mathrm{m} / \mathrm{z}=285$ corresponding to its molecular formula $\mathrm{C}_{15} \mathrm{H}_{15} \mathrm{~N}_{3} \mathrm{O}_{3}$.<smiles>COc1ccc2oc(C)c(C(C)=O)c2c1</smiles>

1

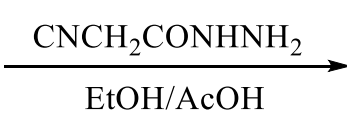

$\mathrm{EtOH} / \mathrm{AcOH}$<smiles>COc1ccc2oc(C)c(/C(C)=N/NC(=O)CC#N)c2c1</smiles>

2 
Chromene derivatives are widely used for the production of highly effective fluorescent pigments (Zahang et al., 2003; Christie et al., 1999). Some derivatives also play an important role in electro photographic and electroluminescent devices (Saski et al., 1994). Moreover, many other derivatives are well known for their significant biological and medicinal activities (Melagraki et al., 2009). Thus, cyclocondensation of $\mathbf{2}$ with salicylaldehyde or 2-hydroxynaphthaldehyde in ethanol containing pipridine furnished smoothly 2-imino- $N$-[1-(5-methoxy-2-methylbenzofuran-3yl)ethylidene]-2H-chromene-3-carbohydrazide and 2-imino- $N$-[1-(5methoxy-2-methylbenzofuran-3-yl)ethylidene]-2H-benzo[ $g$ ]chromene-3-

carbohydrazide (3 and $\mathbf{4}$ ), respectively. The analytical and spectral data of the products are in agreement with the proposed structure. The IR spectrum of 3 showed absorption bands at 3362, 3223 for $(2 \mathrm{NH})$ and $1681 \mathrm{~cm}^{-1}$ for (CO). The ${ }^{1} \mathrm{H}$ NMR (DMSO- $\mathrm{d}_{6}, \delta, \mathrm{ppm}$ ) of 3 revealed signals at $\delta$ (ppm): $2.32\left(\mathrm{~s}, 3 \mathrm{H}, \mathrm{CH}_{3}\right), 2.66\left(\mathrm{~s}, 3 \mathrm{H}, \mathrm{CH}_{3}\right), 3.82\left(\mathrm{~s}, 3 \mathrm{H}, \mathrm{OCH}_{3}\right), 6.84-7.94(\mathrm{~m}, 7 \mathrm{H}$, Ar-H), 8.63 (s, 1H, CH) , 9.27(s, 1H, NH) 13.56 (s, 1H, NH). The molecular weight of 3 was revealed by mass spectra which showed a molecular ion peak at $\mathrm{m} / \mathrm{z}=389$ corresponding to the molecular formula $\mathrm{C}_{22} \mathrm{H}_{19} \mathrm{~N}_{3} \mathrm{O}_{4}$. The IR spectrum of compound 4 exhibited stretching bands at 3406, 3265 for (2NH) and at $1675 \mathrm{~cm}^{-1}$ for (CO). The ${ }^{1} \mathrm{H}$ NMR spectrum (DMSO-d $\left.6, \delta, p p m\right)$ exposed signals at $\delta(\mathrm{ppm}): 2.33\left(\mathrm{~s}, 3 \mathrm{H}, \mathrm{CH}_{3}\right), 2.63\left(\mathrm{~s}, 3 \mathrm{H}, \mathrm{CH}_{3}\right), 3.84(\mathrm{~s}$, $\left.3 \mathrm{H}, \mathrm{OCH}_{3}\right), 6.7-7.8(\mathrm{~m}, 7 \mathrm{H}, \mathrm{Ar}-\mathrm{H}), 8.59$ (s, 1H, CH), $9.16 \quad(\mathrm{~s}, 1 \mathrm{H}, \mathrm{NH})$, $13.51(\mathrm{~s}, 1 \mathrm{H}, \mathrm{NH})$. The mass spectrum showed a molecular ion peak at $\mathrm{m} / \mathrm{z}=$ 439 corresponding to its molecular weight.

Reaction of $\mathbf{2}$ with $p$-anisaldehyde afforded the corresponding anisal derivative 2-cyano- $N$-[1-(5-methoxy-2-methylbenzofuran-3-yl)ethylidene)3-(4-methoxyphenyl]acrylohydrazide(5). The IR spectrum of 5 showed absorption bands at 3318 for (NH), 2212 for $(\mathrm{CN})$ and at $1660 \mathrm{~cm}^{-1}$ for (CO). The ${ }^{1} \mathrm{H}$ NMR spectrum lacked a singlet for methylene group at $4.23 \mathrm{ppm}$ and revealed instead a singlet signal at $7.69 \mathrm{ppm}$ for the newly formed $(\mathrm{CH}=\mathrm{C})$ function. The mass spectrum showed a molecular ion peak at $\mathrm{m} / \mathrm{z}=403$ corresponding to its molecular formula $\mathrm{C}_{23} \mathrm{H}_{21} \mathrm{~N}_{3} \mathrm{O}_{4}$.

The anisal derivative $\mathbf{5}$ was utilized in the synthesis of pyrazole and isoxazole moieties via its reaction with the bifunctional nucleophilic reagents, hydrazine hydrate and hydroxyl amine hydrochloride respectively. Thus heating 5 with hydrazine hydrate in ethanol afforded 5-amino- $N$-[1-(5methoxy-2-methylbenzofuran-3-yl)ethylidene]-3-(4-methoxyphenyl)-1Hpyrazole-4-carbohydrazide (6). The IR spectrum lacked the stretching absorption band for a cyano group with the appearance of a new broad band at 3470 to 3250 for both $(\mathrm{NH})$ and $\left(\mathrm{NH}_{2}\right)$ groups. The ${ }^{1} \mathrm{H}$ NMR spectrum lacked a singlet for methylene group protons and revealed a singlet at 12.23 
ppm for $\mathrm{NH}$ proton of the pyrazole ring. The mass spectrum showed a molecular ion peak at $\mathrm{m} / \mathrm{z}=433$ corresponding to its molecular weight.

carbohydrazide (7). The chemical and spectral data proved its structure. Thus, the IR spectrum lacked absorption for a cyano group with the appearance of a new stretching broad band for $(\mathrm{NH})$ and $\left(\mathrm{NH}_{2}\right)$ groups. The ${ }^{1} \mathrm{H}$ NMR spectrum revealed a new singlet at $6.24 \mathrm{ppm}$ for $\mathrm{NH}_{2}$ with the disappearance of a singlet for methylene group protons at $4.23 \mathrm{ppm}$. Mass spectrum showed a molecular ion peak at $\mathrm{m} / \mathrm{z}=434$ corresponding to its molecular formula $\mathrm{C}_{23} \mathrm{H}_{22} \mathrm{~N}_{4} \mathrm{O}_{5}$ (scheme 1).

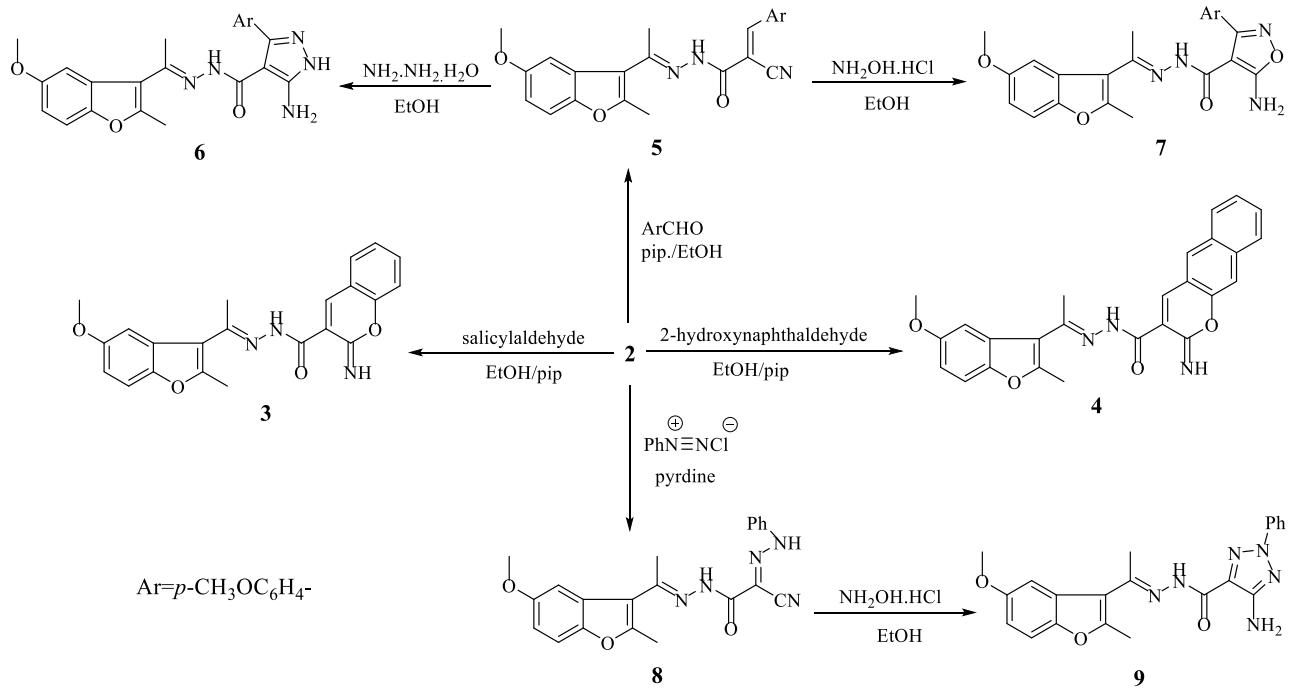

Scheme 1

Next we examined the reactivity of the methylene group present in compound 2 towards diazonium salts. Thus the reaction of $\mathbf{2}$ with benzene diazonium chloride gave the hydrazone derivative 2-[2-(1-(5-methoxy-2methylbenzofuran-3-yl)ethylidene)hydrazinyl]-2-oxo- $N$ -

phenylacetohydrazonoyl cyanide $(\mathbf{8})$. The analytical and spectral data of the product is in consistent with the proposed structure. The IR spectrum showed two characteristic bands at 3435 and 3242 for 2 (NH) groups, stretching band at 2213 for $(\mathrm{CN})$ function and at $1683 \mathrm{~cm}^{-1}$ for $(\mathrm{CO})$ group, while its ${ }^{1} \mathrm{H}$ NMR spectrum displayed five singlet signals at $2.37\left(\mathrm{~s}, 3 \mathrm{H}, \mathrm{CH}_{3}\right), 2.67$ (s, $\left.3 \mathrm{H}, \mathrm{CH}_{3}\right), 3.8\left(\mathrm{~s}, 3 \mathrm{H}, \mathrm{CH}_{3}\right), 10.52(\mathrm{~s}, 1 \mathrm{H}, \mathrm{NH})$ and $11.98(\mathrm{~s}, 1 \mathrm{H}, \mathrm{NH})$ and a multiplet signal at (6.8-7.8) ppm for the aromatic protons. In addition its ${ }^{13} \mathrm{C}$ NMR spectrum which is compatible with its structure. The mass spectrum showed a molecular ion peak at $\mathrm{m} / \mathrm{z}=389$ corresponding to its molecular weight. 
Refluxing the arylhydrazone $\mathbf{8}$ with hydroxylamine hydrochloride in ethanol and triethylamine as a base gave 1,2,3-triazole derivative 5-amino$N^{\prime}$-[1-(5-methoxy-2-methylbenzofuran-3-yl)ethylidene]-2-phenyl-2H-1,2,3triazole-4-carbohydrazide (9) via the amidoxime intermediate (Scheme 2).<smiles>COc1ccc2oc(C)c(/C(C)=N/NC(=O)/C(=N/Nc3ccccc3)NC(C)(Cl)Cl)c2c1</smiles><smiles>COc1ccc2oc(C)c(C(C)=NNC(=O)C(=NNc3ccccc3)C(=N)O)c2c1</smiles>
amidoxime<smiles>COc1ccc2oc(C)c(/C(C)=N/NC(=O)c3nn(-c4ccccc4)nc3N)c2c1</smiles>

Scheme 2

The spectral data for compound 9 proved the correct proposed structure. The IR spectrum showed characteristic bands at $3380(\mathrm{NH}), 3279$ and $3241\left(\mathrm{NH}_{2}\right)$ and $1660 \mathrm{~cm}^{-1}(\mathrm{CO})$ and lacked an absorption band for the cyano group. The ${ }^{1} \mathrm{H}$ NMR spectrum lacked a singlet at $10.52 \mathrm{ppm}$ for $\mathrm{NH}$ group with the appearance of a new singlet signal at $6.4 \mathrm{ppm}$ for $\mathrm{NH}_{2}$ group. Also its mass spectrum showed a molecular ion peak at $\mathrm{m} / \mathrm{z}=404$ corresponding to its molecular formula $\mathrm{C}_{21} \mathrm{H}_{20} \mathrm{~N}_{6} \mathrm{O}_{3}$.

Moreover, Gewald reaction of $\mathbf{2}$ with elemental sulfur and phenyl isothiocyanate in warming ethanol containing triethylamine as a basic catalyst afforded 4-amino- $N$ '-[1-(5-methoxy-2-methylbenzofuran-3yl)ethylidene]-3-phenyl-2-thioxo-2,3-dihydrothiazole-5-carbohydrazide (10). The IR spectrum of compound $\mathbf{1 0}$ showed a broad signal at 3500 - 3391 for $\left(\mathrm{NH}\right.$ and $\mathrm{NH}_{2}$ ) and the absence of the band assignable to the cyano function. The ${ }^{1} \mathrm{H}$ NMR spectrum lacked a singlet at $4.23 \mathrm{ppm}$ for a methylene group and instead revealed a new singlet signal at $7.87 \mathrm{ppm}$ for $\mathrm{NH}_{2}$ group. The mass spectrum showed a molecular ion peak at $\mathrm{m} / \mathrm{z}=452$ corresponding to its molecular weight.

Gewald reaction of the hydrazide hydrazone 2 with cyclopentanone and elemental sulfur in boiling ethanol containing a catalytic amount of morpholine gave the corresponding thiophene derivative 3-amino- $N$-[1-(5methoxy-2-methylbenzofuran-3-yl)ethylidene]-5,6-dihydro- $4 \mathrm{H}$ cyclopenta[b]thiophene-2-carbohydrazide (11). The IR spectrum of compound 11 lacked an absorption bands assignable to a cyano function while revealed the presence of a broad band for both $\mathrm{NH}$ and $\mathrm{NH}_{2}$ groups at 
3500 to $3232 \mathrm{~cm}^{-1}$. The ${ }^{1} \mathrm{H}$ NMR spectrum lacked a singlet for methylene group with the appearance of a multiplet for the cyclopentano protons in the aliphatic region at 2.07 to $2.9 \mathrm{ppm}$.

2-Pyridone derivatives are known to exhibit diverse biological activities (Good et al., 2016) in view of this herein the synthesis of some 2pyridone derivatives via the reaction of compound $\mathbf{2}$ with certain nucleophilic reagents. Thus, when $\mathbf{2}$ was fused with acetylacetone in the presence of a catalytic amount of pipridine a cyclocondensation reaction smoothly afforded 1-[(1-(5-methoxy-2-methylbenzofuran-3-yl)ethylidene)amino]-4,6-dimethyl2-oxo-1,2-dihydropyridine-3-carbonitrile derivative (12).

The IR spectrum of compound 12 exhibited absorption bands at 2214 for $(\mathrm{CN})$ and $1658 \mathrm{~cm}^{-1}$ for $(\mathrm{CO})$. The ${ }^{1} \mathrm{H}$ NMR spectrum revealed five singlet signals for five methyl groups besides a singlet at $6.47 \mathrm{ppm}$ for an olefinic proton and lacked absorption band for (NH). The mass spectrum showed a molecular ion peak at $\mathrm{m} / \mathrm{z}=349$ represents its molecular weight.

In addition we studied the reactivity of the hydrazide hydrazone derivative 2 towards cinnamonitrile. Thus the reaction of 2 with 2benzylidene malononitrile give the pyridine derivative 6-amino-1-[(1-(5methoxy-2-methylbenzofuran-3-yl)ethylidene)amino]-2-oxo-4-phenyl-1,2dihydropyridine-3,5-dicarbonitrile (13).

The analytical and spectral data supported the structure of compound 13. The IR spectrum showed absorption bands at 3404 and $3305 \mathrm{~cm}^{-1}$ for $\left(\mathrm{NH}_{2}\right)$ group. The ${ }^{1} \mathrm{H}$ NMR spectrum lacked two singlet signals for methylene group protons and $(\mathrm{NH})$ with the appearance of new singlet at $8.26 \mathrm{ppm}$ for $\left(\mathrm{NH}_{2}\right)$ group. The mass spectrum showed a molecular ion peak at $\mathrm{m} / \mathrm{z}=437$ corresponding to its molecular formula $\mathrm{C}_{25} \mathrm{H}_{19} \mathrm{~N}_{5} \mathrm{O}_{3}$ (scheme 3).

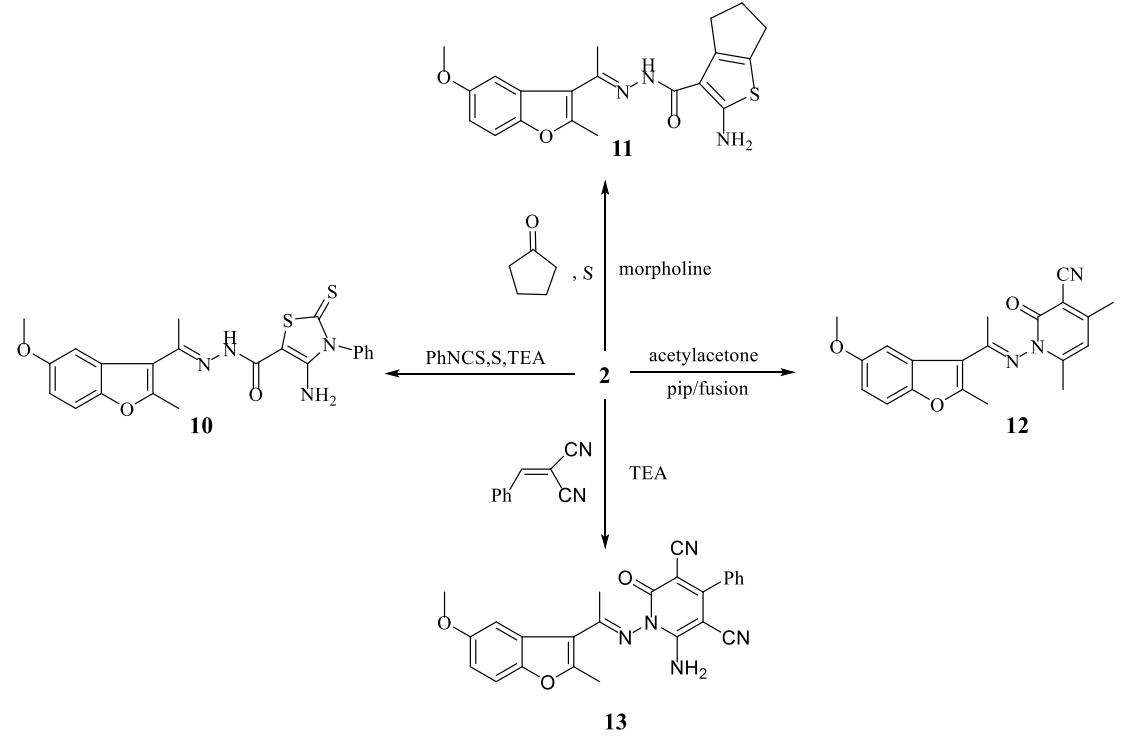

Scheme 3 
The antioxidant activity of the synthesized compounds was evaluated employing the 2,2'-azinobis (3-ethylbenzothiazoline-6-sulfonic acid) (ABTS). Regarding the structure activity relationship (SAR) most of the synthesized compounds showed a good antioxidant activity compared to Vitamin C. Within this context, compounds 9, 11, 5 and 10 showed 87, 84, 83 and $80 \%$ inhibition, respectively. The higher antioxidant of these compounds can be suggested as it depends on the role of antioxidant to remove free radicals. One important mechanism through which this is achieved is by donating hydrogen to free radicals which removes the odd electron feature which is responsible for radical reactivity. So, in these compounds depends on the presence of the amino hydrogen atoms, whereas this atom was under the influence resonance effect among the heterocyclic rings. The tautomer's play an important role in releasing of hydrogen.

According to these suggestions, the rest of the compounds exhibited moderate activity. Fortunately, there was a correlation between the compounds structures and the activity, suggesting that it is not a general benzofuran activity. The trizol-, pyrazol-, isoxazol-, thiophen- based benzofurans were among the most active compounds in this assay which can be stabilize an unpaired electron in general which enhance the antioxidant efficiency of the molecules. Surprisingly, compounds $\mathbf{4}$ and $\mathbf{1 2}$ with pyan and pyridone functionality were the least active in this assay.

Table(1): antioxidant activity of compounds 2-13 by ABTS method

\begin{tabular}{ccc}
\hline Method & \multicolumn{2}{c}{ ABTS } \\
\hline Compounds & Absorbance of samples & $\%$ inhibition \\
2 & 0.122 & $76.1 \%$ \\
3 & 0.082 & $76.5 \%$ \\
4 & 0.196 & $61.6 \%$ \\
5 & 0.120 & $83.9 \%$ \\
6 & 0.062 & $67.0 \%$ \\
7 & 0.077 & $71.4 \%$ \\
8 & 0.151 & $70.4 \%$ \\
9 & 0.168 & $87.8 \%$ \\
10 & 0.192 & $80.4 \%$ \\
11 & 0.100 & $84.9 \%$ \\
12 & 0.146 & $62.3 \%$ \\
13 & 0.128 & $74.9 \%$ \\
Control of ABTS & 0.510 & $0 \%$ \\
\hline
\end{tabular}


Ascorbic-acid

0.056

$89.0 \%$

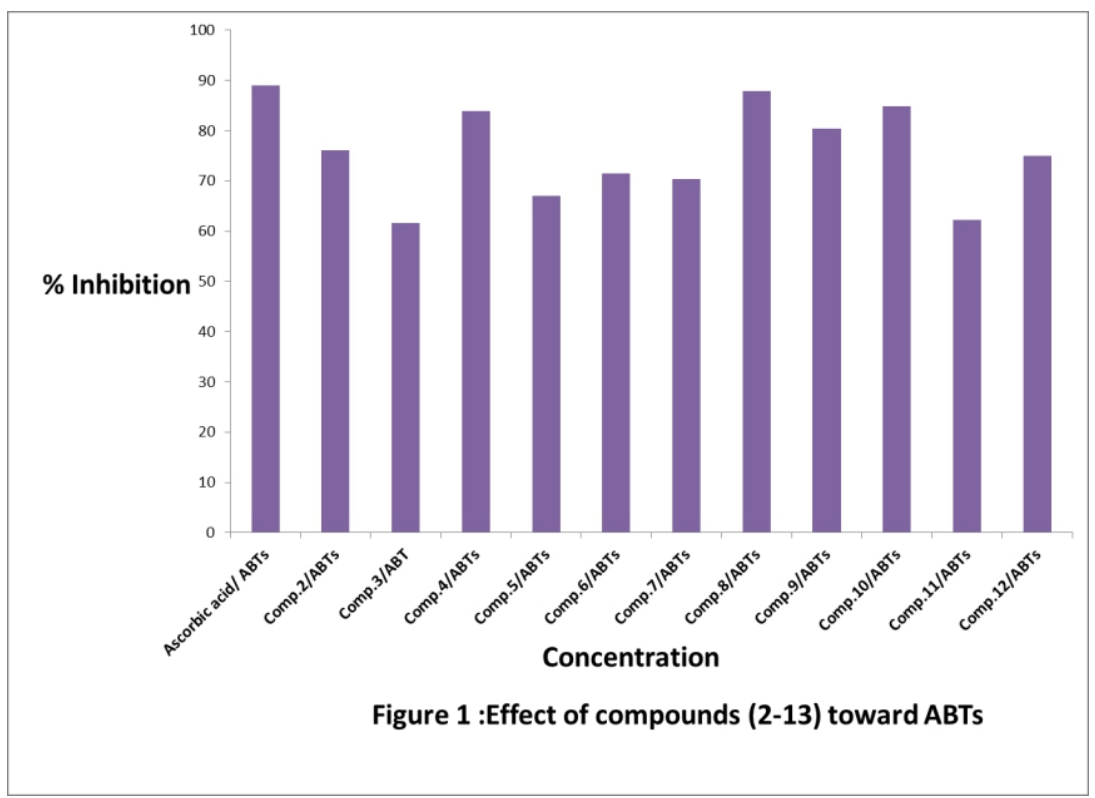

\section{Experimental}

All melting points (uncorrected) are in degree centigrade and were determined on Gallenkamp electric melting point apparatus. Elemental analyses were carried out in the Micro analytical Unit of the Faculty of Science, Cairo University. IR spectra were recorded $(\mathrm{KBr})$ with a Thermo Scientific $^{\mathrm{TM}}$ Nicolet $^{\mathrm{TM}}$ iS $^{\mathrm{TM}} 10$ FT-IR Faculty of Science, Mansoura University. NMR spectra were measured in (DMSO- $d_{6}$ and $\mathrm{CDCl}_{3}$ ) as solvents at $300 \mathrm{MHz}\left({ }^{1} \mathrm{HNMR}\right)$ on a Bruker NMR spectrometer using TMS as internal standard and chemical shifts are expressed as $\delta / p p m$ were carried out in Cairo and Al-Azhar Universities. The mass spectra (EI) were recorded on $70 \mathrm{eV}$ with Kratos MS equipment and/or Varian MAT311ASpectrometer. 3-Acetyl-5-methoxy-2-methylbenzofuran was synthesized according to the previously reported procedures.

\section{2-Cyano- $N$-[1-(5-methoxy-2-methylbenzofuran-3-yl)ethylidene]acetoh- ydrazide (2)}

To a solution of 5-methoxybenzofuran derivative $\mathbf{1}(1 \mathrm{mmol})$ in ethanol containing a catalytic amount of acetic acid an equimolar amount of cyanoacetohydrazide was added, the reaction mixture was heated under reflux for $8 \mathrm{~h}$, cooled to room temperature. The solid formed was filtered off, collected and recrystallized from ethanol to give compound $\mathbf{2}$. 
White crystals; yield (86\%); m.p. $188-90^{\circ} \mathrm{C}$; IR $(\mathrm{KBr}): \mathrm{v} / \mathrm{cm}^{-1}=3197$ (NH), $2262(\mathrm{CN}), 1683 \mathrm{~cm}^{-1}(\mathrm{CO}) .{ }^{1} \mathrm{H}$ NMR (DMSO-d6) $\delta(\mathrm{ppm}): 2.34$ (s, $\left.3 \mathrm{H}, \mathrm{CH}_{3}\right), 2.57\left(\mathrm{~s}, 3 \mathrm{H}, \mathrm{CH}_{3}\right), 3.8\left(\mathrm{~s}, 3 \mathrm{H}, \mathrm{OCH}_{3}\right), 4.23\left(\mathrm{~s}, 2 \mathrm{H}, \mathrm{CH}_{2}\right), 6.8-7.8$ $(\mathrm{m}, 3 \mathrm{H}, \mathrm{Ar}-\mathrm{H}), 11.00(\mathrm{~s}, 1 \mathrm{H}, \mathrm{NH}) ;{ }^{13} \mathrm{C}-\mathrm{NMR}$ (DMSO-d6, $\left.\delta \mathrm{ppm}\right): 165.55$, $156.38,155.78,147.71,127.07,116.08,115.52,112.4,111.11,105.84$, 103.9, 55.45, 25.09, 16.89, 14.63 ; MS (EI, $70 \mathrm{eV}): \mathrm{m} / \mathrm{z}(\%)=285.98\left(\mathrm{M}^{+}\right.$ 2.02), 242.98(17.12), 218(21.37), 200(100), 185.97(37.68), 159.97(73.23), 111(44.47).

Anal. for $\mathrm{C}_{15} \mathrm{H}_{15} \mathrm{~N}_{3} \mathrm{O}_{3}$ (285.5):

Calcd: C, 63.15; H, 5.30; N, $14.73 \%$.

Found: C, 63.16; H, 5.29; N, $14.72 \%$.

\section{Preparation of compounds 3 and 4}

salicylaldehyde (1 mmol) or 2-hydroxynaphthaldehyde (1mmol) was added to a solution of compound $1(1 \mathrm{mmol})$ in ethanol $(25 \mathrm{~mL})$ containing few drops of piperidine and the mixture was heated under reflux for $2 \mathrm{~h}$. The solid products formed was collected by filtration, dried, and recrystallized from DMF/ethanol mixture to afford compound 3, 4.

\section{2-Imino- $N$-(1-(5-methoxy-2-methylbenzofuran-3-yl)ethylidene)-2H- chromene-3carbohydrazide (3)}

Yellow crystals; yield (83\%); mp 218-20 $\mathrm{C}$; IR (KBr): $\mathrm{v} / \mathrm{cm}^{-1}=3362$, 3223 for $2(\mathrm{NH})$ and $1681 \mathrm{~cm}^{-1}$ for (CO). ${ }^{1} \mathrm{H}$ NMR (400 MHz, DMSO-d6): $\delta / \mathrm{ppm}=2.32 \quad\left(\mathrm{~s}, 3 \mathrm{H}, \mathrm{CH}_{3}\right), 2.66\left(\mathrm{~s}, 3 \mathrm{H}, \mathrm{CH}_{3}\right), 3.82\left(\mathrm{~s}, 3 \mathrm{H}, \mathrm{OCH}_{3}\right), 6.8-7.9$ (m, 7H, Ar-H), 8.63 (s, 1H, CH), 9.27 (s, 1H, NH), 13.56 (s, 1H, NH); MS m/z (\%): 389 (M+, 4.2), 217.99 (19.37), 171.96 (100), 144.99 (68.47), 118 (67.26), 89.02 (22).

Anal. for $\mathrm{C}_{22} \mathrm{H}_{19} \mathrm{~N}_{3} \mathrm{O}_{4}(389.96)$ :

Calcd : C, 67.86; H, 4.92; N, $10.79 \%$.

Found: C, 67.85; H, 4.93; N, $10.81 \%$.

\section{2-Imino- $N$-[1-(5-methoxy-2-methylbenzofuran-3-yl)ethylidene]-2H-} benzo $[g]$ chromene-3-carbohydrazide (4)

Yellow crystals; yield (79\%); m.p 236-238 $\mathrm{C}$; IR $(\mathrm{KBr}): \mathrm{v} / \mathrm{cm}^{-1}=$ 3406,3265 for $2(\mathrm{NH}), 1675$ (CO). ${ }^{1} \mathrm{H}$ NMR (400 MHz, DMSO-d6): $\delta$ $(\mathrm{ppm})=2.33\left(\mathrm{~s}, 3 \mathrm{H}, \mathrm{CH}_{3}\right), 2.63 \quad\left(\mathrm{~s}, 3 \mathrm{H}, \mathrm{CH}_{3}\right), 3.84\left(\mathrm{~s}, 3 \mathrm{H}, \mathrm{OCH}_{3}\right), 6.7-7.8$ (m, 7H, Ar-H), 8.59 (s, 1H, CH), 9.16 (s, 1H, NH), 13.51 (s, 1H, NH); MS m/z (\%): 439.07 (M+, 1.18), 388.97 (84.29), 276.96 (47.96), 171.97 (100), 105 (41.45).

Anal. for $\mathrm{C}_{26} \mathrm{H}_{21} \mathrm{~N}_{3} \mathrm{O}_{4}(439.07)$ :

Calcd: C, 71.06; H, 4.82; N, $9.56 \%$.

Found: C, 71.04; H, 4.86; N, $9.51 \%$. 
2-Cyano- $N$-[1-(5-methoxy-2-methylbenzofuran-3-yl)ethylidene)-3-(4methoxyphenyl]acrylohydrazide (5)

A mixture of 3 (1 $1 \mathrm{mmol}), \mathrm{P}$-anisaldehyde $(1 \mathrm{mmol})$ in ethanol $(30$ $\mathrm{mL}$ ) and a few drops of piperidine was refluxed for $3 \mathrm{~h}$. The solid product was collected by filtration and recrystallized from ethanol afforded $\mathbf{5}$.

Yellow sheets; yield (74\%); m.p. 98-100 C; IR(KBr): v/cm-1 = 3318 (NH), $2212(\mathrm{CN}), 1660$ (CO); ${ }^{1} \mathrm{H}$ NMR (DMSO-d6) $\delta$ (ppm): 2.38 (s, 3H, $\left.\mathrm{CH}_{3}\right), 2.66 \quad\left(\mathrm{~s}, 3 \mathrm{H}, \mathrm{CH}_{3}\right), 3.8(\mathrm{~s}, 3 \mathrm{H}, \mathrm{OCH} 3), 3.87\left(\mathrm{~s}, 3 \mathrm{H}, \mathrm{OCH}_{3}\right), 6.8-$ $7.4(\mathrm{~m}, 7 \mathrm{H}, \mathrm{Ar}-\mathrm{H}), 7.69$ (s, 1H, =CH) , 11.1 (s, 1H, NH); MS (EI, $70 \mathrm{eV})$ : $\mathrm{m} / \mathrm{z}(\%)=403(\mathrm{M}+, 87.95), 389(32), 336(100), 285(28.36), 218(98.23)$, 203(95.97).

Anal.for $\mathrm{C}_{23} \mathrm{H}_{21} \mathrm{~N}_{3} \mathrm{O}_{4}(403.44)$ :

Calcd: C, 68.47; H, 5.25; N, $10.42 \%$.

Found: C, 68.45; H, 5.23; N, $10.44 \%$.

\section{3-Amino- $N$-[1-(5-methoxy-2-methylbenzofuran-3-yl)ethylidene)-5-(4- methoxyphenyl]-1H-pyra- zole-4-carbohydrazide (6)}

To a solution of $\mathbf{5}(1 \mathrm{mmol})$ in ethanol $(30 \mathrm{ml})$ an equimolar amount of hydrazine monohydrate was added, the mixture was heated under reflux for $2 \mathrm{~h}$, the solution concentrated to $5 \mathrm{ml}$. the formed product was collected by filtration and recrystallized from ethanol to give compound $\mathbf{6}$.

Yellow crystal; yield (61\%); m.p. 278-81 ${ }^{\circ} \mathrm{C}$; IR(KBr): v/cm-1 = $3470-32502(\mathrm{NH})$ and $\left(\mathrm{NH}_{2}\right)$ and $1660(\mathrm{CO}) ;{ }^{1} \mathrm{H}$ NMR (DMSO-d6) $\delta$ (ppm): 2.32 (s, 3H, $\left.\mathrm{CH}_{3}\right), 2.67\left(\mathrm{~s}, 3 \mathrm{H}, \mathrm{CH}_{3}\right), 3.85$ (s, 3H, $\left.\mathrm{OCH}_{3}\right), 3.87$ (s, 3H, $\left.\mathrm{OCH}_{3}\right), 6.83-7.65(\mathrm{~m}, 7 \mathrm{H}, \mathrm{Ar}-\mathrm{H}), 7.32\left(\mathrm{~s}, 2 \mathrm{H}, \mathrm{NH}_{2}\right), 11.6(\mathrm{~s}, 1 \mathrm{H}, \mathrm{NH}), 12.23$ $(\mathrm{s}, 1 \mathrm{H}, \mathrm{NH}) ; \mathrm{MS}(\mathrm{EI}, 70 \mathrm{eV}): \mathrm{m} / \mathrm{z}(\%)=433(\mathrm{M}-1$ 1.02), 326.1(41.5), 269.2(36), 218(91), 203.9(62.8).

Anal. For $\mathrm{C}_{23} \mathrm{H}_{23} \mathrm{~N}_{5} \mathrm{O}_{4}(433.47)$ :

Calcd: C, 63.73; H, 5.35; N, $16.16 \%$.

Found: C, 63.71; H, 5.32; N, $16.13 \%$.

\section{5-amino- $N$-[1-(5-methoxy-2-methylbenzofuran-3-yl)ethylidene)-3-(4- methoxyphenyl]isoxazole-4-carbohydrazide (7)}

To a solution of $5(1 \mathrm{mmol})$ in ethanol $(30 \mathrm{ml})$ an equimolar amount of hydroxylamine hydrochloride was added, the mixture was heated under reflux for $4 \mathrm{~h}$, the solution concentrated to $5 \mathrm{ml}$. the formed product was collected by filtration and recrystallized from ethanol to give compound 7.

Yellow crystal; yield (73\%); m.p. $262-5^{\circ} \mathrm{C}$; IR(KBr): v $/ \mathrm{cm}^{-1}=3421$ - 3265 for $(\mathrm{NH})$ and $\left(\mathrm{NH}_{2}\right)$ and $1661(\mathrm{CO}) ;{ }^{1} \mathrm{H}$ NMR (DMSO-d6) $\delta$ (ppm): $2.33\left(\mathrm{~s}, 3 \mathrm{H}, \mathrm{CH}_{3}\right), 2.61\left(\mathrm{~s}, 3 \mathrm{H}, \mathrm{CH}_{3}\right), 3.85\left(\mathrm{~s}, 3 \mathrm{H}, \mathrm{OCH}_{3}\right), 3.88(\mathrm{~s}, 3 \mathrm{H}$, $\left.\mathrm{OCH}_{3}\right), 6.24\left(\mathrm{~s}, 2 \mathrm{H}, \mathrm{NH}_{2}\right), 6.7-7.6(\mathrm{~m}, 7 \mathrm{H}, \mathrm{Ar}-\mathrm{H}), 11.92(\mathrm{~s}, 1 \mathrm{H}, \mathrm{NH}) ; \mathrm{MS}$ 
$(\mathrm{EI}, 70 \mathrm{eV}): \mathrm{m} / \mathrm{z}(\%)=434.2(\mathrm{M}+10.24), 403.2(32.5), 327.1(36)$, 244.2(29.8), 218(91.2), 203.4(42.3).

Anal. for $\mathrm{C}_{23} \mathrm{H}_{22} \mathrm{~N}_{4} \mathrm{O}_{5}$ (434.45):

Calcd: C, 63.59; H, 5.10; N, $12.90 \%$.

Found: C, 63.61; H, 5.08; N, $12.88 \%$.

\section{2-[2-(1-(5-Methoxy-2-methylbenzofuran-3-yl)ethylidene)hydrazinyl]-2-} oxo- $N$-phenylacetohydrazonoyl cyanide $(8)$

A cold suspension of benzene diazonium salt $(1 \mathrm{mmol})$ (prepared from $1 \mathrm{mmol}$ of aniline with the appropriate quantities of sodium nitrite and hydrochloric acid) was gradually added to a cold solution $\left(0-5^{\circ} \mathrm{C}\right)$ of compound 1 (1mmol) in pyridine $(10 \mathrm{~mL})$ with continuous stirring for $1 \mathrm{~h}$. The reaction mixture was poured on crushed ice containing hydrochloric acid. The product obtained was filtered off, washed with water and recrystallized from dilute ethanol to give compound $\mathbf{8}$.

Yellow crystals; yield $(70 \%)$; m.p. $229-32^{\circ} \mathrm{C}$; IR $(\mathrm{KBr}): \mathrm{v} / \mathrm{cm}^{-1}=$ 3435, $32422(\mathrm{NH}), 2213(\mathrm{CN}), 1683(\mathrm{CO}) .{ }^{1} \mathrm{H}$ NMR (DMSO-d6) $\delta(\mathrm{ppm})$ : $2.37\left(\mathrm{~s}, 3 \mathrm{H}, \mathrm{CH}_{3}\right), 2.67\left(\mathrm{~s}, 3 \mathrm{H}, \mathrm{CH}_{3}\right), 3.80\left(\mathrm{~s}, 3 \mathrm{H}, \mathrm{OCH}_{3}\right), 6.8-7.8(\mathrm{~m}, 8 \mathrm{H}$, Ar-H), 10.52 (s, $1 \mathrm{H}, \mathrm{NH}), 11.98(\mathrm{~s}, 1 \mathrm{H}, \mathrm{NH}) ;{ }^{13} \mathrm{C}-\mathrm{NMR}$ (DMSO- $d 6, \delta \mathrm{ppm}$ ): 155.27, 153.36, 148.79, ArC 137.19-102.31; MS (EI, $70 \mathrm{eV}): \mathrm{m} / \mathrm{z}(\%)=$ $389.98\left(\mathrm{M}^{+}\right.$3.08), 218.02(100), 203.02(48), 187(19.64), 92.01(23.78), 77.01(38.05).

Anal. for $\mathrm{C}_{21} \mathrm{H}_{19} \mathrm{~N}_{5} \mathrm{O}_{3}(389.98)$ :

Calcd. C, 64.77; H, 4.92; N, $17.98 \%$.

Found: C, 64.75; H, 4.91; N, $17.99 \%$.

\section{5-Amino- $N$-[1-(5-methoxy-2-methylbenzofuran-3-yl)ethylidene]-2- phenyl-2H-1,2,3-triazole-4-carbohydrazide (9)}

A mixture of compound $\mathbf{8}(1 \mathrm{mmol})$ and hydroxylamine hydrochloride $(1 \mathrm{mmol})$ in the presence of drops of triethylamine was refluxed in ethanol $(10 \mathrm{ml})$ for $4 \mathrm{~h}$. The solid precipitate so formed was filtered off and recrystallized from Ethanol as a solvent to give compound 9.

Brown powder; yield (72\%); m.p. $112-4^{\circ} \mathrm{C}$; IR $(\mathrm{KBr})$ : v/cm-1 $=3380$ $(\mathrm{NH}), 3279,3241(\mathrm{NH} 2), 1660(\mathrm{C}=\mathrm{O}) .{ }^{1} \mathrm{H}$ NMR (DMSO-d6) $\delta$ (ppm): 2.32 (s, 3H, CH $\left.\mathrm{CH}_{3}\right), 2.68\left(\mathrm{~s}, 3 \mathrm{H}, \mathrm{CH}_{3}\right), 3.84\left(\mathrm{~s}, 3 \mathrm{H}, \mathrm{OCH}_{3}\right), 6.4\left(\mathrm{~s}, 2 \mathrm{H}, \mathrm{NH}_{2}\right), 6.8-$ $7.9(\mathrm{~m}, 8 \mathrm{H}, \mathrm{Ar}-\mathrm{H}), 11.8(\mathrm{~s}, 1 \mathrm{H}, \mathrm{NH})$; MS (EI, $70 \mathrm{eV}): \mathrm{m} / \mathrm{z}(\%)=404(\mathrm{M}+$ 4.52), 279 (12), 219 (32.5), 203 (100), 149 (38.65).

Anal. for $\mathrm{C}_{21} \mathrm{H}_{20} \mathrm{~N}_{6} \mathrm{O}_{3}(404.43)$ :

Calcd: C, 62.37; H, 4.98; N, $20.78 \%$.

Found: C, 62.35; $\quad \mathrm{H}, 4.93 ; \quad \mathrm{N}, 20.75 \%$. 


\section{2-Amino- $N$-[1-(5-methoxy-2-methylbenzofuran-3-yl)ethylidene]-5,6- dihydro-4H-cyclopenta[b]thiophene-3-carbohydrazide (10)}

To a solution of compound $3(2 \mathrm{mmol})$ in absolute ethanol $(20 \mathrm{~mL})$ containing trimethylamine (5 drops), elemental sulfur $(2 \mathrm{mmol})$ and phenylisothiocyanate $(2 \mathrm{mmol})$ were added. The reaction mixture was heated at $60^{\circ} \mathrm{C}$ for $2 \mathrm{~h}$ with continuous stirring then poured onto beaker containing an ice/water mixture containing few drops of hydrochloric acid. The formed solid product was collected by filtration, dried well, and recrystallized from ethanol to give compound $\mathbf{1 0 .}$

Yellow crystal; yield (70\%); m.p. $214-6^{\circ} \mathrm{C}$; IR(KBr): $\mathrm{v} / \mathrm{cm}^{-1}=3500$ $3391(\mathrm{NH})$ and $\left(\mathrm{NH}_{2}\right), 1681(\mathrm{CO}) ;{ }^{1} \mathrm{H}$ NMR (DMSO-d6) $\delta(\mathrm{ppm}): 2.33$ (s, $\left.3 \mathrm{H}, \mathrm{CH}_{3}\right), 2.72\left(\mathrm{~s}, 3 \mathrm{H}, \mathrm{CH}_{3}\right), 3.80\left(\mathrm{~s}, 3 \mathrm{H}, \mathrm{OCH}_{3}\right), 6.8-7.6(\mathrm{~m}, 8 \mathrm{H}, \mathrm{Ar}-\mathrm{H})$, 7.87 (s, 2H, NH$\left.{ }_{2}\right), 10.99$ (s, 1H, NH); ${ }^{13} \mathrm{C}-\mathrm{NMR}$ (DMSO-d6, $\delta$ ppm):165.55, 163.22, 155.74, 154.7, 147.87, 134.87, 130.11, 128.94, 127.3, 116.16, $112.55,111.32,103.91,103.39,80.133,55.55,30.71,17.4,14.0 ;$ MS (EI, 70 $\mathrm{eV}): \mathrm{m} / \mathrm{z}(\%)=452\left(\mathrm{M}^{+}\right.$8.62), 285(88.15), 243(44.23), 218(100), 203(84.12), 187(39.78).

Anal. for $\mathrm{C}_{22} \mathrm{H}_{20} \mathrm{~N}_{4} \mathrm{O}_{3} \mathrm{~S}_{2}(452.55)$ :

Calcd: C, 58.39; H, 4.45; N, 12.38; S, $14.17 \%$.

Found: C, 58.42; H, 4.46; N, 12.33; S, $14.14 \%$.

\section{3-Amino- $N$-[1-(5-methoxy-2-methylbenzofuran-3-yl)ethylidene]-5,6- dihydro-4H-cyclopenta[b]thiophene-2-carbohydrazide (11)}

To a solution of compound $\mathbf{3}(2 \mathrm{mmol})$ in ethanol $(20 \mathrm{~mL})$ containing morpholine $(0.5 \mathrm{~mL})$, elemental sulfur $(2 \mathrm{mmol})$ and cyclopentanone $(2 \mathrm{mmol})$ were added. The reaction mixture was heated at $60^{\circ} \mathrm{C}$ for $2 \mathrm{~h}$ with continuous stirring, then poured onto beaker containing an ice/water mixture containing few drops of hydrochloric acid. The formed solid product was collected by filtration, dried well, and recrystallized from ethanol to give compound 11.

Brown powder; yield (75\%); m.p. $267-8{ }^{\circ} \mathrm{C}$; IR(KBr): v/cm ${ }^{-1}=3500$ to 3232 for $(\mathrm{NH})$ and $\left(\mathrm{NH}_{2}\right)$ groups and $1640(\mathrm{CO}) ;{ }^{1} \mathrm{H}$ NMR (DMSO-d6) $\delta$ (ppm): $2.07 \quad\left(\mathrm{t}, 2 \mathrm{H}, \mathrm{CH}_{2}\right), 2.17\left(\mathrm{t}, 2 \mathrm{H}, \mathrm{CH}_{2}\right), 2.36\left(\mathrm{~s}, 3 \mathrm{H}, \mathrm{CH}_{3}\right), 2.7(\mathrm{~m}$, $\left.2 \mathrm{H}, \mathrm{CH}_{2}\right), 2.73\left(\mathrm{~s}, 3 \mathrm{H}, \mathrm{CH}_{3}\right), 3.80\left(\mathrm{~s}, 3 \mathrm{H}, \mathrm{OCH}_{3}\right), 6.8-7.4(\mathrm{~m}, 3 \mathrm{H}, \mathrm{Ar}-\mathrm{H})$, 7.69 (s, 2H, NH$), 11.23$ (s, 1H, NH); MS (EI, $70 \mathrm{eV}): \mathrm{m} / \mathrm{z}(\%)=383\left(\mathrm{M}^{+}\right.$ 10.42), 275(74.32), 247(55.87), 218(100), 203(89.12), 187(39.78).

Anal. for $\mathrm{C}_{20} \mathrm{H}_{21} \mathrm{~N}_{3} \mathrm{O}_{3} \mathrm{~S}(383.47)$ :
Calcd: C, 62.64;
H, 5.52; N, 10.96;
$\mathrm{S}, 8.36 \%$.
Found: C, 62.63;
$\mathrm{H}, 5.55 ; \quad \mathrm{N}, 10.99$;
S, $8.32 \%$.

\section{1-[(1-(5-Methoxy-2-methylbenzofuran-3-yl)ethylidene)amino]-4,6- dimethyl-2-oxo-1,2-dihydropyridine-3-carbonitrile (12)}


A mixture of compound $\mathbf{1}(1 \mathrm{mmol})$ and acetyl acetone $(1.2 \mathrm{mmol})$ in ethanol $(15 \mathrm{~mL})$ containing few drops of piperidine was fused for $2 \mathrm{~h}$ in an oil bath at $150^{\circ} \mathrm{C}$. The reaction mixture was cooled and the solid so obtained was filtered off and purified using TLC technique using (ethyl acetate: petroleum ether) as an eluent to give compound $\mathbf{1 2 .}$

Yellow crystal; yield (70\%); m.p. 193-5 C; IR(KBr): $\mathrm{v} / \mathrm{cm}^{-1}=2214$ (CN), $1658 \mathrm{~cm}^{-1}$ (CO); ${ }^{1} \mathrm{H}$ NMR (DMSO-d6) $\delta$ (ppm): $2.21\left(\mathrm{~s}, 3 \mathrm{H}, \mathrm{CH}_{3}\right.$ ), $2.33\left(\mathrm{~s}, 3 \mathrm{H}, \mathrm{CH}_{3}\right), 2.39\left(\mathrm{~s}, 3 \mathrm{H}, \mathrm{CH}_{3}\right), 2.74\left(\mathrm{~s}, 3 \mathrm{H}, \mathrm{CH}_{3}\right), 3.78\left(\mathrm{~s}, 3 \mathrm{H}, \mathrm{OCH}_{3}\right)$, $6.47(\mathrm{~s}, 1 \mathrm{H}, \mathrm{CH}), 6.9-7.5(\mathrm{~m}, 3 \mathrm{H}, \mathrm{Ar}-\mathrm{H}) ;{ }^{13} \mathrm{C}-\mathrm{NMR}$ (DMSO-d6, $\left.\delta \mathrm{ppm}\right)$ : $154.1,149.4,146.7,137.7,130.2,122.4,118.5,115.4,112.2,110.2$, $104.6,92.1,55.8,21.2,20.8,19.9 ;$ MS (EI, $70 \mathrm{eV}): \mathrm{m} / \mathrm{z}(\%)=349.98$ $\left(\mathrm{M}^{+}\right.$4.55), 333.97(19.27), 201.01(100), 159.98(75.72), 131.98(31.57), 89.02(17.33).

Anal. for $\mathrm{C}_{20} \mathrm{H}_{19} \mathrm{~N}_{3} \mathrm{O}_{3}$ (349.98):

Calcd: C, 68.75; H, 5.48; N, $12.03 \%$.

Found: C, 68.72; H, 5.45; N, $12.08 \%$.

\section{4-Amino-5-benzylidene-6-imino-1-[(1-(5-methoxy-2-methylbenzofuran- 3-yl)ethylidene)amino]-2-oxo-1,2,5,6-tetrahydropyridine-3-carbonitrile (13)}

An equimolar amount of compound $1(1 \mathrm{mmol})$ and few drops of triethylamine were added to a solution of the arylidenemalononitrile ( 1 $\mathrm{mmol})$ in ethanol $(20 \mathrm{~mL})$. The mixture was refluxed for $2 \mathrm{~h}$, then left to cool to room temperature. The solid product that formed was collected by filtration then recrystallized from ethanol to give the corresponding pyridin2-one derivative $\mathbf{1 3}$.

Yellow crystal; yield (64\%); m.p. $230-2^{\circ} \mathrm{C}$; $\mathrm{IR}(\mathrm{KBr}): \mathrm{v} / \mathrm{cm}^{-1}=3404$, $3305\left(\mathrm{NH}_{2}\right), 2216,2191$ for $2(\mathrm{CN})$ and $1674(\mathrm{CO}) ;{ }^{1} \mathrm{H}$ NMR (DMSO-d $) \delta$

(ppm): 2.3

$2.76\left(\mathrm{~s}, 3 \mathrm{H}, \mathrm{CH}_{3}\right)$,

(s, 3H, $\left.\mathrm{CH}_{3}\right), 2.6\left(\mathrm{~s}, 3 \mathrm{H}, \mathrm{CH}_{3}\right), 2.73\left(\mathrm{~s}, 3 \mathrm{H}, \mathrm{CH}_{3}\right)$, $\mathrm{Ar}-\mathrm{H}), 8.26\left(\mathrm{~s}, 2 \mathrm{H}, \mathrm{NH}_{2}\right) ; \mathrm{MS}: \mathrm{m} / \mathrm{z}(\%)=437\left(\mathrm{M}^{+} 48\right), 388(55.47), 248$ (2.99), 218 (62.77), 187 (100), 91(45.31).

Anal. for $\mathrm{C}_{25} \mathrm{H}_{19} \mathrm{~N}_{5} \mathrm{O}_{3}(437.47)$ :

Calcd: C, 68.64; H, 4.38; N, $16.01 \%$.

Found: C, 68.61; H, 4.41; N, $15.96 \%$.

\section{Conclusion}

In summary, we have reported the synthesis of a series of new benzo[b]furan derivatives linked to different types of heterocyclic rings as pyridine, trizol-, pyrazol, isoxazol, thiophen, chromene and pyridone. The newly synthesized compounds were characterized by their elemental and spectral data (IR, ${ }^{1} \mathrm{H}$ NMR and MS). Screening for some selected 
compounds was carried for their potential antioxidant activities using ABTS. Compounds 9, 11, 5 and 10 showed the higher inhibition. compounds $\mathbf{4}$ and 12 with were the least active.

\section{References:}

1. Abdel-Rahman A. H., Kandeel E. M., Berghot M. A., Abedel-Motaal M. (2013) J Heterocyclic Chem. 50, 298.

2. Baraldi P. G., Romagnoli R., Bianchib N., Gambarib R. (2003) Med. Chem. 11, 2381.

3. Berghot M. A., Kandeel E. M., Abdel-Rahaman A. H., Abdel-Motaal M. (2014) Med chem. 4(3), 381.

4. Bondock S., El-Azap H., Kandeel E. M., Metwally M. A. (2008) Monatsh Chem. Christie R. M., Chih-Hung L. (1999) Dyes Pigm. 42, 85 .

5. Deshpande R., Bhagawan Raju M., Parameshwar S., Shanth Kumar S.M., Appalaraju S. and Yelagatti M. S. (2012) Am. J. Chem. 2, 115.

6. El-Desoky S. I., Kandeel E. M., Abdel-Rahamn A. H., Schmidt R. R. (1998) Z.Naturforsch. 53b, 1216.

7. El-Sawy E. R. , Ebaid M. S. , Abo-Salema H. M. , Al-Sehemib A. G. , Mandoura A. H. , Shin D. S. (2014)Tetrahedron Lett. 55, 2796.

8. Flynn B. L., Hamel E., Jung M. K. (2002) J. Med. Chem. 45, 2670.

9. Gadaginamath G. S., Kavali R. R. and Pujar S. R. (2003) Synth Commun. 33(13), 2285.

10. Good J. A., Silver J., Núñez-Otero C., Bahnan W., Krishnan K. S., Salin O., Engström P., Svensson R., Artursson P., Gylfe A., Bergström S., Almqvist F. (2016) J. Med. Chem. 59(5), 2094.

11. Gopalsamy A., Aplasca A., Ciszewski G., Park K., Ellingboe J. W., Orlowski M., Feld B., Howe A. Y. M. (2006) Bioorg. Med. Chem. Lett. 16, 457.

12. Guru S. G., Rajesh R. K., Shashikanth R. P. (2003) Synth Commun. 33(13), 2285. Zahang Y. Y., Meng X. M., Wang X. L., Xu L. X. (2003) Dyes Pigm. 56, 189.

13. Hirosato E., Miyako M., Pingli L., Ken-ichi K., Morikami K., Sogabe S., Hayase M., Fujii T., Sakata K., Shindoh H., Shiratori Y., Aoki Y., Ohtsukaa T., Nobuo Shimma (2002) Bioorg. Med. Chem. Lett. 12, 607.

14. Hranjec M., Sovic I., Ratkaj I., Pavlovic G., sallic N., Valjalo L., Pavelic K., Pavelic S. K., Karminski-Zamola G. (2013) Eur. J. Med. Chem. 59, 111.

15. Hsieh J. F., Lin W. J., Huang K. F., Liao J.H., Don M. J., Shen C. C., Shiao Y. J., Li W. T. (2015) Eur. J. Med. Chem. 26(93), 443. 
16. Kamal A., Reddy N. V. S., Nayak V. L., Reddy V. S., Prasad B., Nimbarte V. D., Srinivasulu V., Vishnuvardhan M. V. P. S., Reddy C. S. (2014) Chem Med Chem. 9, 117.

17. Khan I. A., Kulkarni M. V., Gopal M., Shahabuddin M. S., Sun C.M. (2005) Bioorg. Med. Chem. Lett. 15, 3584.

18. Malpania Y., Acharya R., Kim S. Y., Jeong H. C., Kim P., Han S. B., Kim M., Lee C. K., Kim J. N., Jung Y.-S. Eur. (2013) J. Med. Chem. 62, 534.

19. Manna K., Agrawal Y. K., Design (2010) Eur. J. Med. Chem. 45, 3831.

20. Melagraki G., Afantitis A., Igglessi-Markopoulou O., Desti A., Koufaki M., Kontogiorgis C., Hadjipavlou-Litina D. (2009) Eur. J. Med. Chem. 44, 3020.

21. Messina, F. and Botta M. (2000) Tetrahedron Asym. 11, 4895.

22. Metwally M. A., Bondock S., El-Azap H., Kandeel E. M. (2011) J Sulphur Chem. 32(5), 489.

23. Parekh S., Bhavsar D., Savant M., Thakrar S., Bavishi A., Parmar M., Vala H., Radadiya A., Pandya N., Serly J., Molnar J., Shah A. (2011) Eur. J. Med. Chem. 46, 1942.

24. Prado S., Ledeit H., Michel S., Koch M., Darbord J. C., Cole S. T., Tillequin F., Brodin P. (2006) Bioorg. Med. Chem. 14, 5423.

25. Rida S. M., EI-Hawash S. A. M., Fahmy H. T. Y., Hazzaa A. A., EIMeligy M. M. M. Arch. Pharm. (2006) Res. 29, 826.

26. Reshma J. N., Santosh N. D., Satish N. D. (2015) Eur. J. Med. Chem. 97, 561.

27. Wu J., Li Y., Chen K., Jiang H., Xu M.-H., Liu D. (2013) Eur. J. Med. Chem. 60, 441.

28. Romagnoli, R. Baraldi, P. G. Carrion, Cara M. D. C. L., Cruz-Lopez O., Tolomeo M., Grimaudo S., Di Cristina A., Pipitone M. R., Balzarini J., Zonta N., Brancale A., Hamel E., (2009) Design, Med. Chem. 17, 6862.

29. Saski K., Koki K. (1994) 23, 190; chem. Abst. 1994, 120:310929a.

30. Takaya D., Yamashita A., Kamijo K., Gomi J., Ito M., Maekawa S., Enomoto N., Sakamoto N., Watanabe Y., Arai R., Umeyama H., Honma T., Matsumoto T., Yokoyama S. (2011)Bioorg. Med. Chem. $19,6892$.

31. Verma A., Pandeya S. N. and Sinha S. (2011) Int. J. Res. Ayurveda Pharm. 2, 1110.

32. Wang X. -Q., Liu L. -X., Li Y., Sun C. -J., Chen W., Li L., Zhang H. -B., Yang X.-D. (2013) Eur. J. Med. Chem. 62, 111.

33. Xiea Y. S., Kumar D., Bodduri V. D. V., Tarani P. S., Zhao B. X., Miao J. Y., Jang K., Shin D. -S. (2014)Tetrahedron Lett. 55, 2796. 
34. Yadav P., Singh P., Tewari A. K. (2014) Bioorg. Med. Chem. Lett. 24, 2251.

35. Yeung, K. S. (2012) Heterocycl. Chem. 29, 47. 